\title{
A Survey on the Continuing Education Status and Demand of Nurses in Chongqing Grass-Root Medical Institutions
}

\author{
Tong $\mathrm{Li}^{1,2}$ \\ ${ }^{1}$ Department of Oral and Maxillofacial Surgery, The First Affiliated Hospital of Chongqing Medical University, Chongqing, China \\ ${ }^{2}$ Research Center for Medicine and Social Development, School of Public Health and Management, Chongqing Medical \\ University, Innovation Center for Social Risk Governance in Health, Chongqing, China \\ Email: t11986127@126.com
}

How to cite this paper: Li, T. (2020) A Survey on the Continuing Education Status and Demand of Nurses in Chongqing Grass-Root Medical Institutions. Open Journal of Nursing, 10, 155-170. https://doi.org/10.4236/ojn.2020.102010

Received: January 16, 2020

Accepted: February 15, 2020

Published: February 18, 2020

Copyright $\odot 2020$ by author(s) and Scientific Research Publishing Inc. This work is licensed under the Creative Commons Attribution International License (CC BY 4.0).

http://creativecommons.org/licenses/by/4.0/ (c) (i) Open Access

\begin{abstract}
Background: With the increased aging of population, the continuous increase in the morbidity of chronic diseases, and the issuance of universal two-child policy, the grass-root medical teams become more and more important. Objective: To investigate the continuing education status and demand of nurses in the grass-root medical institutions and thus provide a reference for optimizing the continuing education plan. Methods: From October 2018 to May 2019, a survey of 270 nurses from 28 grass-root medical institutions in Tongliang District of Chongqing was performed using a self-designed questionnaire. Results: In the grass-root medical institutions, the major continuing education pattern of nurses was hospital training and distance education; the continuing education focused on new basic theoretical knowledge and new nursing techniques, and its satisfaction was $67.8 \%$. About 20.6\% questionnaire answerers never had received continuing nursing education. As shown by one-way analysis of variance (ANOVA) and binary logistic regression analysis, the following factors were associated with the continuing education participation in the past three years: work unit, organizational affiliation, age, professional title and hospital policies. There were 93.0\% questionnaire answerers reflecting that it was necessary to participate in the continuing education and wishing the conformance between the pattern and contents of continuing nursing education and the actual implementation status. Conclusion: The continuing education demand of nurses in the grass-root medical institutions is basic but diverse, and the organizations shall provide effective policy support for continuing education and make the diversified training plan by combining Internet technology, so as to realize the maximization of continuing education participation and keep improving the overall service quality of gross-root nurses.
\end{abstract}




\section{Keywords}

Gross-Root Medical Institution, Nurse, Continuing Education, Demand

\section{Introduction}

With the change of disease spectrum and the increased aging of population, "strengthening the gross-root" becomes one of keys in the new medical reform. The gross-root nurses, as a member of the medical technician team, play an important role in the hierarchical diagnosis and treatment, chronic disease management, geriatric nursing, and community service; however, they have differential core competencies, and there is an imbalance of overall horizontal development [1] [2]. To promote the service level and improve the nursing quality, the nurses must keep receiving the continuing education in the whole professional career [3]. As mentioned in the " $13^{\text {th }}$ five-year" national medical and family planning talent development plan, the targeted continuing medical education (CME) of multiple patterns for all kinds of medical and family planning technicians (e.g., traditional Chinese doctors, pharmacists, nurses and technicians) in the urban and rural gross-root medical institutions shall be enhanced to increase the post competence. The domestic investigators have completed many studies of continuing education in the grass-root nurse teams, but these studies focus on different topics. This study aimed to investigate the continuing education status and demand of nurses in Chongqing gross-root medical institutions and thus provide a reference for the development of optimal continuing education plan.

\section{Objects and Methods}

\subsection{Study Objects}

The gross-root medical institutions of lower than the district level in Tongliang District of Chongqing were selected from October 2018 to May 2019, including 5 community health service centers and 23 township hospitals, but excluding the village clinics with $<3$ nurses. A survey was performed on 270 nurses. The inclusion criteria were described as follows: 1) registered nurses with nurse licenses; 2) nurses who had engaged in the grass-root nursing work for $\geq 1$ year. All nurses were voluntary to participate in this survey.

\subsection{Survey Tools}

This survey was conducted using a self-designed questionnaire. The questionnaire included three parts: 1) personal general data, including work unit, sex, age, post, professional title, education, organizational affiliation, and so on; 2) continuing nursing education status, including continuing education participation in the past three years, satisfaction to continuing education efficacy, reasons for no or rare participation in the continuing education, and unit support; 3 ) 
continuing nursing education demand, including continuing education intention, continuing education pattern, continuing education contents, funds and expenditures, etc. The reliability and validity test showed that the reliability coefficient was 0.960 .

\subsection{Data Collection Methods}

We successfully sought for the cooperation and assistance from Department of Medical Administration, Tongliang Health Commission. Firstly, a questionnaire pre-survey was performed and then the questionnaire was modified according to the problems found in the pre-survey. Secondly, a survey was conducted by convenient cluster sampling. Totally 270 questionnaires were distributed to various grass-root medical institutions in the whole district and then uniformly filled by study objects under the organization of Department of Medical Administration, Tongliang Health Commission. To guarantee the questionnaire filling quality, the investigators adopted the uniform instructions and provided the detailed statement about the survey significance and the contents, filling and notes of questionnaires. Finally, 256 (94.8\%) eligible questionnaires were collected.

\subsection{Statistical Analysis}

SPSS 21 software was used for statistical analysis. The qualitative data were analyzed by descriptive statistics with frequency and percentage. For continuing education participation in the past three years, the demographic data and work data of participation group and non-participation group were compared using $x^{2}$ test. The factors related with continuing education participation were analyzed by binary logistic regression analysis; the variables were screened by forward selection, backward elimination and enter regression, and then the screened differential variables were included into the final regression model. For variable screening, the inclusion and exclusion criteria of variables were both $p=0.05$. The co-linearity among independent variables was diagnosed with the variance inflation factor, and the variance inflation factor $<5$ indicated no co-linearity. The significance level for all analyses was $p<0.05$.

\section{Results}

\subsection{Demographic Data of Nurses in the Grass-Root Medical Institutions}

There were 256 nurses, including 55 from community health service centers and 201 from township hospitals; 7, 109, 63 and 14 nurses were aged $\leq 25,26-35,26$ - 45 and $\geq 46$ years, respectively. Among these nurses, 231 were post nurses and 25 were head nurses; 119 were nurses with professional titles, 66 were senior nurses, 55 were supervisor nurses, and 12 were co-chief and chief nurses; 34 , 156,64 , and 1 nurse had secondary vocational education, junior college education, Bachelor education and Master education, respectively. In the organizational affiliation, 133 nurses were established and 123 nurses were non-established. 


\subsection{Continuing Education Status of Nurses in the Grass-Root Medical Institutions}

\subsubsection{Overview of Continuing Nursing Education}

The continuing nursing education pattern included hospital training (77.0\%), distance education (62.0\%), academic conferences (32.0\%) and self-study (27.0\%). The continuing education contents involved new basic theoretic knowledge $(71.5 \%)$, new nursing techniques $(62.0 \%)$, nursing safety $(56.0 \%)$, health education (47.5\%), nursing teaching (36.0\%), and nursing management (34.5\%). In the efficacy of continuing nursing education, $67.8 \%, 30.2 \%$ and $2.0 \%$ nurses felt satisfactory, acceptable and unsatisfactory, respectively. The reasons for no or rare participation in the continuing education were busy work (54.8\%), rigid pattern (21.7\%), high costs (20.7\%), and quota limit (10.1\%). The details are shown in Table 1.

Table 1. Data of continuing education.

\begin{tabular}{|c|c|}
\hline Item & $\mathrm{N}(\%)$ \\
\hline \multicolumn{2}{|l|}{ Continuing nursing education pattern (multiple choices) } \\
\hline Hospital training & $154(77.0 \%)$ \\
\hline Distance education & $124(62.0 \%)$ \\
\hline Self-study & $54(27.0 \%)$ \\
\hline Academic conferences/lectures & $64(32.0 \%)$ \\
\hline Workshops & $13(6.5 \%)$ \\
\hline Seminars & $10(5.0 \%)$ \\
\hline Correspondence courses & $19(9.5 \%)$ \\
\hline Other & $17(8.5 \%)$ \\
\hline Advanced education & $8(4.0 \%)$ \\
\hline \multicolumn{2}{|l|}{ Continuing nursing education contents (multiple choices) } \\
\hline New basic theoretic knowledge & $143(71.5 \%)$ \\
\hline New nursing techniques & $124(62.0 \%)$ \\
\hline Nursing teaching & $72(36.0 \%)$ \\
\hline Nursing management & $69(34.5 \%)$ \\
\hline Nursing safety & $112(56.0 \%)$ \\
\hline Health management and health education & $95(47.5 \%)$ \\
\hline Psychological nursing knowledge & $34(17.0 \%)$ \\
\hline Nursing scientific research knowledge & $11(5.5 \%)$ \\
\hline Behavioral and social science knowledge & $18(9.0 \%)$ \\
\hline $\begin{array}{l}\text { Reasons for no or rare participation in continuing nursing education (multiple } \\
\text { choices) }\end{array}$ & 217 \\
\hline No unit support & $17(7.8 \%)$ \\
\hline No personal interest to continuing education & $11(5.1 \%)$ \\
\hline
\end{tabular}




\section{Continued}

Too busy work

$119(54.8 \%)$

No family support

$6(2.8 \%)$

Low practicability of continuing education contents

$18(8.3 \%)$

Quota limit

$22(10.1 \%)$

A low pass rate of graduation examination

$12(5.5 \%)$

Rigid pattern

$47(21.7 \%)$

Few information acquisition channels

$8(3.7 \%)$

Lack of continuing learning atmosphere and environment

$15(6.9 \%)$

High costs

$45(20.7 \%)$

Other

$1(0.5 \%)$

\subsection{2. "Blind Zone" of Continuing Education}

In the investigated nurses from the gross-root medical institutions, $20.6 \%$ never had received continuing nursing education, of which $96.2 \%$ were aged $\leq 35$ years, $82.7 \%$ had $\leq$ junior college education, and all had professional titles of $\leq$ senior nurse.

\subsubsection{One-Way ANOVA}

With continuing education participation in the past three years as grouping variable, the following factors were included into the statistical analysis: work unit, sex, age, professional title, post, education, organizational affiliation, unit support, and hospital policies (Table 2). The factors related with the continuing education participation in the past three years were work unit $(p=0.004)$, organizational affiliation $(p<0.001)$, age $(p<0.001)$ and professional title $(p<$ $0.001)$. It indicated that more nurses working in the community health service centers and with a bigger age, a higher professional title and "established" organizational affiliation participated in the continuing nursing education.

\subsubsection{Binary Logistic Regression Analysis}

The setting of variables was same as the above, i.e., work unit (community health service center, $O R=0.09, p<0.001$; reference variable: township hospital), organizational affiliation (established, $O R=0.02, p<0.001$; reference variable: Bachelor education), and hospital polices ( $p=0.008$; reference variable: satisfactory). The results are shown in Table 3. This further indicated that more nurses working in the community health service centers, with "established" organizational affiliation and who had higher satisfaction to hospital policies participated in the continuing education.

\subsection{Continuing Education Demand of Nurses in the Gross-Root Medical Institutions}

In all questionnaire answerers, $93.0 \%$ reflected that it was necessary to participate in the continuing education. The purpose of continuing education participation 
Table 2. Data of grass-root nurses included into the study.

\begin{tabular}{|c|c|c|c|c|}
\hline \multirow{3}{*}{ Characteristics } & \multicolumn{2}{|c|}{ Continuing education in the past three years } & \multirow{3}{*}{$C h I^{2}$} & \multirow{3}{*}{$p$} \\
\hline & Participation & No participation & & \\
\hline & $\mathrm{N}(\%)$ & $\mathrm{N}(\%)$ & & \\
\hline Work unit & & & 8.10 & 0.004 \\
\hline Community health service center & $48(94.1 \%)$ & $3(5.9 \%)$ & & \\
\hline Township hospital & $147(76.2 \%)$ & $46(23.8 \%)$ & & \\
\hline Sex & & & 3.96 & 0.202 \\
\hline Male & $0(0 \%)$ & $1(100 \%)$ & & \\
\hline Female & $197(80.1 \%)$ & $49(19.9 \%)$ & & \\
\hline Age (year) & & & 22.66 & $<0.001$ \\
\hline$\leq 25$ & $46(67.6 \%)$ & $22(32.4 \%)$ & & \\
\hline $26-35$ & $80(74.1 \%)$ & $28(25.9 \%)$ & & \\
\hline $36-45$ & $60(96.8 \%)$ & $2(3.2 \%)$ & & \\
\hline$>45$ & $14(100 \%)$ & $0(0 \%)$ & & \\
\hline Post & & & 2.83 & 0.243 \\
\hline Head nurse & $22(91.7 \%)$ & $2(8.3 \%)$ & & \\
\hline $\begin{array}{l}\text { Administrative secretary of } \\
\text { nursing department }\end{array}$ & $1(100 \%)$ & $0(0 \%)$ & & \\
\hline Nurse & $174(77.7 \%)$ & $50(22.3 \%)$ & & \\
\hline Professional title & & & 31.46 & $<0.001$ \\
\hline Chief/co-chief nurse & $12(100 \%)$ & $0(0 \%)$ & & \\
\hline Supervisor nurse & $54(100 \%)$ & $0(0 \%)$ & & \\
\hline Senior nurse & $55(83.3 \%)$ & $11(16.7 \%)$ & & \\
\hline Nurse & $76(65.5 \%)$ & $40(34.5 \%)$ & & \\
\hline Education & & & 3.64 & 0.162 \\
\hline Secondary vocational education & $23(69.7 \%)$ & $10(30.3 \%)$ & & \\
\hline Junior college education & $119(78.3 \%)$ & $33(21.7 \%)$ & & \\
\hline Bachelor or above education & $55(85.9 \%)$ & $9(14.1 \%)$ & & \\
\hline Organizational affiliation & & & 57.80 & $<0.001$ \\
\hline Established & $129(97.7 \%)$ & $3(2.3 \%)$ & & \\
\hline Non-established & $68(58.6 \%)$ & $48(41.4 \%)$ & & \\
\hline Unit support & & & 5.61 & 0.061 \\
\hline No support & $13(86.7 \%)$ & $2(13.3 \%)$ & & \\
\hline Unknown & $16(61.5 \%)$ & $10(38.5 \%)$ & & \\
\hline Support & $166(80.6 \%)$ & $40(19.4 \%)$ & & \\
\hline Hospital policies & & & 1.96 & 0.375 \\
\hline Satisfactory & $131(76.6 \%)$ & $40(23.4 \%)$ & & \\
\hline Unknown & $26(83.9 \%)$ & $5(16.1 \%)$ & & \\
\hline Unsatisfactory & 39 (84.8\%) & $7(15.2 \%)$ & & \\
\hline
\end{tabular}


Table 3. Factors related with continuing education participation in the binary logistic regression analysis.

\begin{tabular}{lcc}
\hline \multicolumn{1}{c}{ Variable $^{\mathrm{a}}$} & OR $(95 \% C I)$ & $p$ \\
\hline Work unit & $0.09(0.03-0.34)$ & $<0.001$ \\
\multicolumn{1}{c}{ Community health service center } & Reference & \\
Township hospital & & \\
Organizational affiliation & $0.02(0.01-0.08)$ & \\
Established & Reference & 0.001 \\
Non-established & & \\
Hospital policies & Reference & 0.008 \\
Satisfactory & $0.49(0.14-1.72)$ & 0.267 \\
Unknown & $0.18(0.06-0.54)$ & 0.002 \\
\hline
\end{tabular}

${ }^{\mathrm{a} D e p e n d e n t ~ v a r i a b l e s ~ i n c l u d e d ~ i n t o ~ t h e ~ r e g r e s s i o n ~ e q u a t i o n: ~ c o n t i n u i n g ~ e d u c a t i o n ~ p a r t i c i p a t i o n ; ~ i n d e p e n-~}$ dent variables: work unit, sex, age, post, professional title, education, organizational affiliation, unit support, and hospital policies.

was "acquiring the professional knowledge" (68.4\%), "improving the operation skills" (58.8\%), and "conferring of professional titles" (33.2\%). The continuing nursing education pattern was expected to be distance education (69.7\%), hospital training (68.9\%), and academic conferences/lectures (35.9\%). The continuing nursing education contents were expected to be new nursing techniques (81.7\%), new basic theoretic knowledge (73.7\%), and nursing safety $(57.8 \%)$ (Table 4).

\section{Discussion}

\subsection{Analysis on the Continuing Education Status of Nurses in the Grass-Root Medical Institutions}

\subsubsection{Overall Analysis}

The demographic data showed that the grass-root nurse team were young and had low professional titles and low education, which is consistent with the study results of Fu Lili and Chen Shengyu et al. [4]. The continuing education pattern was mainly hospital training and distance education, because they were more convenient than academic conferences, advanced education and other resource acquisition channels, required less time and low costs, and were easier for units to organize and implement. The continuing education contents focused on new basic theoretic knowledge, new nursing techniques and nursing safety, maybe because most grass-root nurses had $\leq$ junior college education and $\leq$ junior professional titles. The nurses had low satisfaction to the efficacy of continuing education, and only $2 / 3$ of them felt satisfactory, which is lower than the study results of Miao Maoyun and Zhang Xiangfeng et al. [5]; the possible reason is that the grass-root medical institutions provide few standard and systematic nurse training platforms and channels for nurses [6]. Based on the survey results, 
Table 4. Continuing education demand.

\begin{tabular}{|c|c|}
\hline Item & $\mathrm{N}(\%)$ \\
\hline \multicolumn{2}{|l|}{ Necessity of continuing education participation } \\
\hline Necessary & $238(93.0 \%)$ \\
\hline Unknown & $15(5.6 \%)$ \\
\hline Unnecessary & $3(1.2 \%)$ \\
\hline \multicolumn{2}{|c|}{ Purpose of continuing education participation (multiple choices) } \\
\hline Conferring of professional titles & $83(33.2 \%)$ \\
\hline Acquiring the professional knowledge & $171(68.4 \%)$ \\
\hline Improving the operation skills & $147(58.8 \%)$ \\
\hline Promoting the scientific research capacity & $38(15.2 \%)$ \\
\hline Other & $12(4.8 \%)$ \\
\hline \multicolumn{2}{|c|}{ Desired continuing nursing education pattern (multiple choices) } \\
\hline Hospital training & $173(68.9 \%)$ \\
\hline Distance education & $175(69.7 \%)$ \\
\hline Self-study & $71(28.3 \%))$ \\
\hline Academic conferences/lectures & $90(35.9 \%)$ \\
\hline Workshops & $76(30.3 \%)$ \\
\hline Seminars & $28(11.2 \%)$ \\
\hline Correspondence courses & $58(23.1 \%)$ \\
\hline Other & $0(0 \%)$ \\
\hline Advanced education & $0(0 \%)$ \\
\hline \multicolumn{2}{|c|}{ Desired continuing nursing education contents (multiple choices) } \\
\hline New basic theoretic knowledge & $185(73.7 \%)$ \\
\hline New nursing techniques & $205(81.7 \%)$ \\
\hline Nursing teaching & $100(39.8 \%)$ \\
\hline Nursing management & $98(39.0 \%)$ \\
\hline Nursing safety & $145(57.8 \%))$ \\
\hline Health management and health education & $122(48.6 \%)$ \\
\hline Psychological nursing knowledge & $106(42.2 \%)$ \\
\hline Nursing scientific research knowledge & $47(18.7 \%)$ \\
\hline Behavioral and social science knowledge & $65(25.9 \%)$ \\
\hline
\end{tabular}

a half of nurses failed to participate or rarely participated in the continuing education because of busy work, and 1/5 nurses complained about rigid pattern and high costs, which is similar to the study results of Li Shujin and Tang Wenguo et al. [7]. It indicates that when carrying out the continuing education activities, the relevant organization departments (e.g., hospitals) shall fully combine the actual clinical work situation, adopt more flexible course teaching modes, con- 
sider the limited learning time of nurses, and provide fund assurance to improve the participation and satisfaction of continuing education.

\subsubsection{Analysis of "Blind Zone"}

As shown by the survey, 1/5 grass-root nurses never had received continuing nursing education in the past three years, and their demographic data indicated that over $90 \%$ were aged $\leq 35$ years and had $\leq$ junior professional titles, they were the young strength of the grass-root nurse team, and their professional quality was closely associated with the overall service level of grass-root nurses [8]. These nurses become the population to be forgotten when the continuing education activities are carried out, so the organizations shall pay importance and actively take measures to eliminate the "blind zone". The factors influencing the continuing education participation included work unit, age, professional title, organizational affiliation and satisfaction to hospital policies. All 5 community health service centers were all in the county urban area and had a bigger distance advantage than township hospitals in obtaining the continuing education resources from the district people's hospital and other superior hospitals; meanwhile, their service objects were more than those of township hospitals, which gives stronger external motivation of learning to the nurses [9]; thus, compared with township hospitals, more nurses working in the community health service centers participated in the continuing education activities. Furthermore, the nurses with high professional titles had a higher professional foundation and higher self-orientation [10], and most of them were paid importance in cultivation by the hospitals and leaders together with the established nurses; thus, these nurses had more chances to participate in the continuing education. In the satisfaction to hospital policies, higher continuing education participation initiative of nurses depends on more importance to the capability promotion of nurses, more support to the continuing education participation of nurses, and more excellent incentive measures from the hospitals. It is easily seen that the work unit, age, professional title and organizational affiliation are relatively fixed and difficultly changed in a short time, while the hospital policy measures can be conveniently taken to influence the continuing education participation of grass-root nurses. Therefore, the leadership can fully consider the influence of the nurse team during the policy development process to encourage the continuing education behaviors.

\subsection{Analysis on the Continuing Education Demand of Nurses in the Grass-Root Medical Institutions}

Over $90 \%$ grass-root nurses believed that it was necessary to participate in the continuing education activities, which is slightly higher than the percentage in the study of Miao Maoyun and Zhang Xiangfeng et al. [11]. It may be somewhat associated with the national policy incline to "strengthening the grass-root" since the $13^{\text {th }}$ five-year, and shows that the grass-root nurses have a positive attitude to continuing education and can be fully aware of continuing education 
importance, but there is still a certain space for promotion. The purpose of continuing education participation was mainly "acquiring the professional knowledge" and "improving the operation skills", which indicates that under the social background of an increasing chronic disease morbidity, population aging, and two-child policy issuance and facing the day-by-day increasing health demand of people, the grass-root nurses know their defects in professional knowledge and professional skills and wish to promote their professional service capability by continuing nursing education. The desired continuing education pattern was mainly distance education and hospital training, which is coincident to the actual implementation pattern. Most grass-root nurses in this study were aged $\leq 35$ years, which is just a peak age group of childbirth and education and also a key period of vocational development. Combining the above analysis showing that the nurses complained about busy work for no or rare participation in the continuing education, the continuing education pattern of a short time, a small distance and rapid access is expected. The desired continuing nursing education contents were new nursing techniques, new theoretic knowledge and nursing safety, which is similar to the actually acquired contents; however, the desired contents proportion was significantly higher than the actual contents proportion. This suggests that the continuing education demand of grass-root nurses is basic and becomes diverse gradually, and the actually implemented continuing education activities cannot meet such demand, so the organization departments shall enlarge the width and depth of continuing education contents.

\section{Conclusion}

The nurse teams in the grass-root medical institutions are generally younger and have low education, low professional titles, and low satisfaction to the current continuing education activities. And their demand for continuing education is basic and dominantly focuses on basic theoretical knowledge and operation skills, but demonstrates diversity. Therefore, the organizations shall provide effective policy support for continuing education and make the diversified training plan by combining Internet technology, so as to realize the maximization of continuing education participation and keep improving the overall service quality of gross-root nurses.

\section{Suggestions}

\subsection{Organizational Level}

\subsubsection{Human Resource Support}

Since the implementation of new medical reform, the grass-root nurses bear heavy work and their nursing scope is gradually enlarged, while insufficient human resources restrict the promotion of nursing service level and the participation of continuing education to a certain degree [12]. Therefore, the leadership shall fully consider the demand, enrich the human resources of grass-root 
nurses, optimize the post configuration, and reduce the waste of human recourses; meanwhile, the leadership shall provide more learning convenience for nurses under the current conditions by flexible shift arrangement and learning time supplementation to increase the continuing education participation.

\subsubsection{Policy and Institutional Support}

Despite an awareness of the importance of continuing nursing education, the grass-root management departments fail to establish the systematic and standard continuing education procedures, and there are different assessment systems in various regions [13]. Partial nurses only participate in the continuing education for getting credits, and it is suggested that the competent units complete the continuing education training system of grass-root nurses and realize the urban-township equal and homogenous training modes and assessment systems. In addition, these units are suggested to enlarge the incentive strength to provide reimbursement for learning funds and promotion chances for encouraging the active participation of nurses, thus achieving the full coverage of continuing education and maximizing the utilization and stabilization of the current grass-root nurse team.

\subsubsection{Network Technical Support}

The development of Internet offers a new possibility of learning. The studies have shown that Internet-based learning can enhance the training efficacy and has such advantages as no geographic limitation, effective realization of training resource sharing, and training time saving [14] [15] [16]. The relevant departments shall actively explore the training modes meeting the demand of the times, positively make a response to "Internet + nursing", and create a "digital and mobile" ubiquitous learning platform and resources to be accessed at any time and at any place by such means as remote network, teleconference, CD-ROM, WeChat, QQ group and app [17] [18], so that the nurses have no worries about the training quota, traveling time and funds and can make full use of fragmented time, thus eliminating the work-learning conflict and realizing the purpose of training without "a long trip".

\subsubsection{Content Resource Support}

The demand of nurses for continuing education contents in this study was in a primary stage but demonstrated diversity, perhaps because the work scope of nurses in the grass-root medical institutions gradually extended to the prevention of chronic diseases, geriatric nursing, health education, prevention and health care, and psychological nursing. The leadership departments shall pay importance to the learning demand of nurses, work out the training contents with such demand as guidance, increase the fund input of open learning resources, break through the task-based learning thinking of "non-conformance with the actual work" and "learning just for learning", and practice the continuing nursing education using several education patterns to really promote the overall quality of grass-root nurses. 


\subsection{Personal Level}

The grass-root nurses shall improve the self-efficacy and internal learning motivation [19], establish a life-long learning idea, positively acquire the learning resources using multi-dimensional learning channels [20], and coordinate the conflict between family and learning; besides, they shall widen the learning contents on the basis of mastering the basic theories and basic skills to continuously meet the demand of people and facilitate the realization of "everyone has access to health care services".

Our study contents and data are true and reliable. However, this study has some limitations below: only the nurses from the grass-root medical institutions in a district of Chongqing were selected as study objects, and there was a small sample size.

\section{Conflicts of Interest}

The author declares no conflicts of interest regarding the publication of this paper.

\section{References}

[1] Peng, G.Y. and Li, Q. (2016) Survey of Nursing Talents Demands of Primary Health Care Institutions in Human Province. Journal of Nursing Research, 30, 4327-4329.

[2] Sun, H.Y., Liu, Y., Zhou, Z.X., Xia, L.P. and Sun, G.Z. (2018) Investigation on Grass-Root Nurses' Core Competency in Jiangsu Province. Chinese Journal of Nursing, 53, 226-230.

[3] An, W.H., Huang, H., Liu, J., Fan, S.S. and Yao, A.H. (2018) Research Progress of Continuing Nursing Education in China. Journal of Nurses Training, 33, 118-120.

[4] Fu, L.L. and Chen, S.Y. (2018) Survey on the Work Tasks of Nurses in the Primary Medical Institutions. Chinese Journal of Nursing, 53, 473-476.

[5] Miao, M.Y., Zhang, X.F., Liu, Y. and Long, N. (2018) Status Quo of Continuing Education Demand of Two Levels of Nursing Staff in County and Township in Shandong Province. Journal of Nursing Research, 32, 1291-1293.

[6] Tu, S.T. and Xie, L.L. (2018) Qualitative Study on the Work Environment Status of Nurses in Chongqing Community Health Service Institutions. Nursing Journal of Chinese People's Liberation Army, 35, 27-30.

[7] Li, S.J., Tang, W.G., Li, B.Q., He, Q.P. and Zhou, M. (2016) Continuing Education Status of Nurses in Sichuan Grass-Root Hospitals and Its Measures. Journal of North Sichuan Medical College, 31, 926-929.

[8] Kong, J., Chen, H.Y., Zhang, Y.Q., Li, D.L., Wang, J. and Wang, R. (2016) Research Status on the Core Competency of Community Nurses. Chinese Journal of Clinical Rational Drug Use, 9, 178-179.

[9] Yang, H.J., Sun, G.H. and Li, M.S. (2019) Survey on the Motivation and Influential Factors of Nurses for the Participation in Continuing Education. Chinese Journal of Medicine, 37, 810-812.

[10] Hu, Q.Y., Wang, Z.Y., Mao, L.L. and Han, J.X. (2018) Survey of Demands of Nurses of Different Competence Grades on Continuing Education and Training in a Third Hospital. Journal of Nursing Research, 32, 461-463. 
[11] Miao, M.Y., Zhang, X.F., Liu, Y. and Zheng, S. (2018) A Survey on the Demand of Continuing Education Contents from Nurses in Township Hospitals. Journal of Nursing Research, 32, 2593-2596.

[12] Tian, Y.H. (2018) Thinking about the Status of Nursing Personal Resources in the Township Hospitals and Its Measures. Chinese Journal of Rural Medicine and Pharmacy, 25, 67-68.

[13] Gai, K., Zhang, J.L. and Liu, W. (2018) Exploration of Nursing Education Status and Innovative Development Strategies in China. Technology Trend, No. 19, 245.

[14] Wang, Y., Qi, M.M. and Chen, X.X. (2016) Systematic Assessment on the Efficacy of Nurse On-the-Job Training by Electronic Learning. Journal of Nurses Training, 31, 579-585.

[15] Shao, Z.F., Gao, Y.N., Hou, X.J. and Chen, J. (2019) Application of Mobile Learning in Nursing Education. Chinese General Practice Nursing, 17, 2193-2197.

[16] Luo, X., Jiang, Y.S. and Liu, Y.Z. (2018) Application and Prospective of Mobile Learning in Academic Continuing Education. Distance Education of China, No. 6, 68-74.

[17] You, H.Q. (2019) Application of Blended Teaching under the Ubiquitous Learning Environment in the Vocational Nursing Teaching Practice. Health Vocational Education, 37, 96-97.

[18] Liu, Y., Li, W.Q. and Zhang, W.Y. (2018) Mobile Learning Training Needs of Nurses. Journal of Nursing Science, 33, 61-64.

[19] Jin, Y.L., Zhang, H.L., Hu, H.X. and Wang, J.Y. (2017) Analysis on the Motivation of In-Service Clinical Nurses for the Participation in Continuing Education. Journal of Nursing Research, 31, 4267-4269.

[20] Cheng, S.S., Ma, X.Q., Ren, L.Y. and Yang, X.T. (2018) Continuing Education of Nurses in Zhejiang Province. Chinese Journal of Nursing Education, 15, 618-623. 


\section{Annex}

\section{Questionnaire for A Survey on Continuing Education Status of Nurses in Chongqing Grass-root Medical Institutions}

To whom it may concern,

This is an anonymous questionnaire to investigate the continuing education status of nurses in the grass-root medical institutions, and there are no wrong or correct answers. Your answers will be only used for academic research but not published. Please fill the questionnaire according to your actual situation and honest opinions. Thank you for taking time to fill it!

$\checkmark$ Mark $[\sqrt{ }]$ in the corresponding item according to your actual situation.

I) General data

1) Work unit: $\square$ Community health service center (station) $\square$ Township hospital

2) Sex: $\square$ Male $\square$ Female

3) Age: $\square \leq 25$ years $\square 26$ - 35 years $\square 36$ - 45 years $\square 46$ - 55 years $\square>55$ years

4) Post: $\square$ Director of nursing department $\square$ Head nurse

$\square$ Administrative secretary of nursing department $\square$ Nurse

5) Professional title: $\square$ Chief nurse $\square$ Co-chief nurse $\square$ Supervisor nurse $\square$ Senior nurse $\square$ Nurse

6) Highest education: $\square<$ Secondary vocational education $\square$ Secondary vocational education

$\square$ Junior college education $\square$ Bachelor education $\square$ Master education

7) Organizational affiliation: $\square$ Established $\square$ Non-established

II) Participation in the continuing nursing education

8) Did you participate in the continuing nursing education within the past three years? (if "no", please answer "Question 17")

$\square$ Yes $\square$ No

9) What are the continuing nursing education patterns you have participated in the past three years? (multiple choices)

$\square$ Hospital training $\square$ Distance education $\square$ Self-study $\square$ Academic conferences/lectures $\square$ Workshops $\square$ Seminars $\square$ Correspondence courses $\square$ Other $\square$ Advanced education

10) How long is your continuing nursing education at each time?

$\square \leq 1$ day $\square 2-4$ days $\square 5-7$ days $\square>7$ days

11) Where have you participated in the continuing nursing education?

$\square$ In the hospital $\square$ In the district $\square$ In Chongqing $\square$ In other cities

12) What is the annual frequency of your participation in the continuing nursing education?

$\square 1$ - 2 times $\square 3$ - 4 times $\square 5$ - 6 times $\square>6$ times

13) Who is the sponsor of continuing nursing education you have participated? (multiple choices)

$\square$ Work hospital $\square$ District-level hospital $\square$ City-level hospital $\square$ Medical associations $\square$ Administrative institutions $\square$ Medical colleges and universities $\square$ 
Other

14) What are the main contents of continuing nursing education you have participated? (multiple choices)

$\square$ New basic theoretic knowledge $\square$ New nursing techniques $\square$ Nursing teaching

$\square$ Nursing management $\square$ Nursing safety $\square$ Health management and health education

$\square$ Psychological nursing knowledge $\square$ Nursing scientific research knowledge

$\square$ Behavioral and social science knowledge

15) What is the main source of funds for continuing nursing education you have participated?

$\square$ Unit payment $\square$ Personal payment

$\square$ Partial unit payment and partial personal payment (personal payment ratio: $\square 1 / 2 \square 1 / 3 \square 1 / 4 \square<1 / 4)$

16) Do you feel satisfactory about the efficacy of continuing nursing education?

$\square$ Very unsatisfactory $\square$ Unsatisfactory $\square$ Acceptable $\square$ Satisfactory $\square$ Very satisfactory

17) Why do you not or rarely participate in the continuing nursing education? (multiple choices)

$\square$ No unit support $\square$ No personal interest in continuing education $\square$ Busy work and no time $\square$ No family support $\square$ Low practicability of continuing education contents $\square$ Quota limit

$\square$ A low pass rate of graduation examination $\square$ Rigid pattern $\square$ Few information acquisition channels $\square$ Lack of continuing learning atmosphere and environment $\square$ High costs $\square$ Other

18) What is the attitude of your work unit to the staff participation of continuing education activities?

$\square$ No support $\square$ No high support $\square$ Unknown $\square$ Support $\square$ High support

III) Demand for continuing nursing education

19) Do you think it is necessary to participate in the continuing nursing education?

$\square$ Very necessary $\square$ Necessary $\square$ Unknown $\square$ Unnecessary

20) What is your main purpose to participate in the continuing nursing education?

$\square$ Conferring of professional titles $\square$ Acquiring the professional knowledge

$\square$ Improving the operation skills $\square$ Promoting the scientific research capacity $\square$ Other

21) Which continuing nursing education contents are expected? (multiple choices)

$\square$ New basic theoretical knowledge $\square$ New nursing techniques $\square$ Nursing teaching

$\square$ Nursing management $\square$ Nursing safety $\square$ Health management and health 
education

$\square$ Psychological nursing knowledge $\square$ Nursing scientific research knowledge

$\square$ Behavioral and social science knowledge

23) Which continuing nursing education pattern would you like to choose? (multiple choice)

$\square$ Hospital training $\square$ Distance education $\square$ Self-study $\square$ Academic conferences/lectures $\square$ Advanced education $\square$ Workshops $\square$ Seminars $\square$ Correspondence courses $\square$ Other 24) Do you think which annual participation frequency of continuing nursing education is suitable?

$\square$ 1-2 times $\square 3-4$ times $\square 5-6$ times $\square>6$ times

25) Do you think how long is suitable for continuing nursing education at each time?

$\square \leq 1$ day $\square 2-4$ days $\square 5-7$ days $\square>7$ days

26) Do you think which personal payment ratio for continuing nursing education is suitable?

$\square$ No personal payment $\square$ Personal payment

$\square$ Partial unit payment and partial personal payment (personal payment ratio: $\square 1 / 2 \square 1 / 3 \square 1 / 4 \square<1 / 4)$

IV) Job satisfaction

27) Satisfaction to your job

$\square$ Satisfactory $\square$ Very satisfactory $\square$ Acceptable $\square$ Very unsatisfactory $\square$ Unsatisfactory

28) Satisfaction to the implementation of hospital policies

$\square$ Satisfactory $\square$ Very satisfactory $\square$ Acceptable $\square$ Very unsatisfactory $\square$ Unsatisfactory

29) Satisfaction to your income and work load

$\square$ Satisfactory $\square$ Very satisfactory $\square$ Acceptable $\square$ Very unsatisfactory $\square$ Unsatisfactory

30) Satisfaction to your working conditions

$\square$ Satisfactory $\square$ Very satisfactory $\square$ Acceptable $\square$ Very unsatisfactory $\square$ Unsatisfactory

31) Satisfaction to the sense of achievement from your job

$\square$ Satisfactory $\square$ Very satisfactory $\square$ Acceptable $\square$ Very unsatisfactory $\square$ Unsatisfactory 